\author{
Rafał Czekaj \\ ๑ https://orcid.org/ 0000-0003-3214-5602 \\ Uniwersytet Marii Curie-Skłodowskiej w Lublinie \\ rafal.czekaj@poczta.umcs.lublin.pl
}

\title{
REGIMES OF IDENTIFICATION OF ART
}

\begin{abstract}
The problem of the demarcation of art and the efforts of analytical philosophy to work out the definition of art were the key issues in aesthetics through most of the 20th century. Those issues emerged from recognizing the impossibility of indicating any sufficient or substantial attributes to being art. Instead of working out the definition the theorists eventually focused on the context which can by essential for recognize some actions or objects as an art. In my paper I cite one of the contemporary efforts of solution of that issues. I am referring to Jaques Rancière's "regimes of art," which can be consider as frames for not only interpretation of art but mostly as condition for recognition of art as visible. In other words: the dominant discourse decides what is recognized as art or what is visible as art. I will briefly present his "regimes of art" and I will try to confront them with one of the examples of contemporary socially engaged art.
\end{abstract}

Keywords: regimes of art, Jacques Rancière, Friedrich Schiller, Purchase of tears

"Nor is there always art, though there always are poetry, painting, music, theatre, dance, sculpture and so on" - these are Jacques Rancière's words from Aesthetics and its Discontents. ${ }^{1}$ However, the statement can generally be read in nearly all his texts containing reflections on art although it is formulated in a different way. Rancière's writings constitute a relatively obvious statement: various forms of artistic creation had existed from the early history of human culture, yet there was no notion which would be broad enough to integrate the variety into one concept - "art". It was impossible to grasp the specific idea of what could not be considered artistic, and thus to distinguish "art" from other manifestations of human creativity. It was modern thought that allowed for an unassailable definition to emerge. The formula of les beaux arts is based

\footnotetext{
1 J. Rancière, Aesthetics and its Discontents, transl. S. Corcoran, Oxford, Polity Press, 2009, p. 26.
} 
on an assumption that only fine arts can be regarded as genuine art. In other words, its author Charles Batteux considered the substance of artistic practice a mimetic function oriented towards beauty. ${ }^{2}$ In a simplified approach one may agree that due to his ideas certain consensus on how art should be defined was reached in Western culture, however, some internal differences of opinion could not be avoided. Anyway the relative unanimity did not last for a long time as the whole construction of "fine arts" was almost completely dismantled by the artistic experiments from the first decades of the 20th century.

The creation of the concept of "fine arts" coincided with the emergence of modern esthetics which to a large extent considered the subject matter of its studies, which was fundamental for its identity, as synonymous with artistic beauty. In confrontation with the avant-garde revolutions which abandoned traditional forms and functions of art not only the subject of esthetic research lost its focus but also the dividing line between art and non-art faded away. This gave rise to the rhetoric of crisis which dominated esthetics throughout the second half of the 20th century. One of the outcomes of those crisis-time discussions was Arthur Danto's conception of "Artworld” and George Dickie's so called "institutional theory of art" which developed Danto's idea. ${ }^{3}$ Both conceptions can be interpreted as a manifestation of capitulation of esthetic reflection in the face of inability to define their subject. Danto and Dickie seem to be speaking unisono: now we are unable to indicate any common features of all the objects which are works of art understood as products of artistic activities; thus let us stop wasting time and energy seeking the answer to the question "what is art?" and tackle the context in which art appears, let us address the field in which works of art occur. The field instituting art was what they called "the world of art" or "a social institution of art".

There are many examples which perfectly illustrate the strength of the field of art and its power in creating artistic objects. One of them can be the casus of the film Air Crash (Katastrofa) directed by Artur Żmijewski, produced in 2010, which documented inter alia the events which took place outside the Presidential Palace in Warsaw after the Smoleńsk disaster. It depicts the rituals of national mourning; it also presents relations of both witnesses and passersby demonstrating different level of knowledge about what actually happened on the airfield near Smoleńsk. In the same year the film Solidarity 2010 (Solidarni 2010) directed by Ewa Stankiewicz and Jan Pospieszalski was released which not only presents the same topic but formally it is not substantially different from Żmijewski's Katastrofa. However, both "productions" have a different sta-

\footnotetext{
See: Ch. Batteux, Les beaux arts réduits à un seul principe, Paris, 1747.

See: G. Dziamski, Postmodernizm wobec kryzysu estetyki wspótczesnej (Postmodernism and the crisis of modern esthetics), Wydawnictwo Naukowe UAM, Poznań 1996.
} 
tus: Katastrofa is regarded as an artistic product while Solidarni 2010 is merely a documentary. The main distribution channels of the former were art galleries, which was appropriate for an artistic product, whereas the documentary by Ewa Stankiewicz and Jan Pospieszalski was broadcast by TV stations. The source of the differences would have been unknown but for the fact that in 2010 Żmijewski was a resident of the 29th Biennale in Săo Paulo and his film was commissioned and financed by the Brazilian curators and constituted an integral part of the exposition.

Another example, or rather a real anecdote, is a story I was told by Professor Leszek Mądzik -director of the Artistic Scene at KUL (Scena Plastyczna KUL). Well, an art gallery in southern Poland offered to organize an exhibition of his works which was also to include elements of his scenic design. The artist packed the selected exhibits, put them into a trailer and on the way to the gallery he stopped at a petrol station to buy a special brush with an intention to use it to clean high windows in his house. He threw the brush into the trailer and continued his journey. After arriving at his destination he left the trailer together with its contents in the hands of the employees and set out on the journey back to Lublin. He completely forgot about the brush. A few weeks passed and he received the catalogue showing the exhibits, including the brush which was bought at the petrol station. Although the story can be treated as an anecdote, it throws some light onto the mechanisms and procedures in which the social institution of art can function.

Jacques Rancière whose words were quoted at the beginning of the article does not explore directly the issue of "the world of art", yet it is implicite present in his reflection. It can be seen, for example, in the way he deals with the concept of "art". The way in which he uses the notion does not aspire towards unambiguous designation of particular objects. "Art" is merely an adopted regime of identification which brings some objects into view; it is optical tuning of perception of those objects that makes us see them as art. It is as if a beam of light was passed through the prism which splits the light in such a way that some objects are illuminated while the others remain in the darkness. Art has always been characterized by certain features although it has never been the same. This means that the prism can split the light in different ways. It is perfectly seen, for example, in the way we use the concept "modern art" these days. Saying "modern art" we usually mean the objects which simply replaced the exhibits previously displayed in galleries. The name "painting", as well as "sculpture" and "dance" or "poetry" and "literature" in general refer only to a certain regime of art's visibility. Photography is also a certain regime of art's visibility, just like video-installation or performance. ${ }^{4}$ And without these spe- 
cific forms of visibility and their discursiveness there is no art at all as it is them that constitute it, or in other words - they make art visible. An ancient craftsman just cast bronze shapes and figures, and the fact that now they are treated as manifestation of art depends solely on our interpretation. Rancière distinguishes three criteria of interpretation: ethics, representation, and esthetics. He explains what lies behind the terms using an example of a Roman statue of Juno - a Roman counterpart of the Greek goddess Hera, known as Junona Ludivisi.

At first sight we merely perceive the statue as representation of a figure from the ancient pantheon of gods, thus we begin to consider it to be an image of a deity.

In this regime, there is property speaking no art as such but instead images that are judged in terms of their intrinsic truth and their impact on the ways of Being of individuals and of the collectivity. This is why I have proposed that the regime in which art enters into a zone of indistinction should be referred to as an ethical regime of images. ${ }^{5}$

The term "the regime of indistinction of art" is used here - the reason is that in this case art as such is not recognized. Here, the statue is the same thing as chairs or tables. Objects can be different only with regard to their status which is defined by the answers to the question about the origin of a work, its purpose and application, and in the case of the statue by the question about the effects evoked by the object. What is a source of strength of its impact? The issue is content - the inner truth which is also to act outwards, its aim is to produce effects and results. It is to format the community according to the recommendations of a particular doctrine; in this case its representative is the Roman goddess Juno. Rancière calls this regime of interpretation "ethical". "Ethical" means: respecting the directive, i.e. whether and to what extent we will accept the message conveyed by the piece. The work presents a certain ethos determined by its content and its requirements must be complied with by individuals and communities. ${ }^{6}$ Nearly the whole Medieval art of the western world functioned in this regime of interpretation. The purpose of Biblia pauperum was not solely and exclusively telling stories from the life of Jesus, primarily it was to build, reinforce, reproduce, and shape the life of the community according to the principles of the Christian doctrine. This was also the case with the art of socialist realism. Submitting it to the ethical regime of interpretation determined its visibility. The term "socialist realism" itself shows that it is not only

\footnotetext{
5 Ibid., p. 28.

6 See: Ibid., p. 21.
} 
a realistic way of presenting an idea that is relevant, the form should also convey a particular social message which would help to shape the ethos supporting the building of the socialist system. It was not merely art filled with ideology and propaganda. To see art in the ethical regime is simply to read its content, this "inner truth".

Another regime of interpretation, perhaps the closest to popular understanding of art, is the regime of representation. Basically, the representation of something presented must be adequate.

(...) this regime (...) identifies the arts - what Classical Age would later call the "fine arts" - within a classification of ways of doing and making, and it consequently defines proper ways of doing and making as well as means of assessing imitations. I call it representative in so far as it is the notion of representation or mimesis that organizes these ways of doing, making, seeing, and judging. ${ }^{7}$

Returning to Rancière's example, i.e. the statue of Juno, we are interested in adequate representation of our idea of the goddess. In addition, the statue is also a portrait of a Roman patrician Antonia Minor. As it frequently happened, the person paying for an effigy wanted to order their own portrait or an image of a family member, in this case we have to do with a picture of a real person, her identity is known; those who knew Antonia Minor could make their own judgment - to what extent the model's features were successfully reproduced by the sculptor. In other words, the regime of representation formats our perception of art as a certain combination of form and matter. In addition, art without mimetic intentions can also function successfully within this regime. The form must be in a certain way attractive or convincing. Thus, there is also a place for non-figurative art here.

The third system identified by Rancière is the esthetic regime. I thoroughly discussed it on another occasion, so here I merely want to show that he can be regarded as one of the contemporary theorists trying to redefine a traditional horizon of what is esthetic, which actually is an attempt to regain the already known intuitions characteristic of the classics of modern esthetics. ${ }^{8}$ The esthetic regime of interpretation does not deal with potential sensual allure of artistic objects. The esthetic form of visibility of art is rooted in the fact that an object is perceived as belonging to a different sensorium than the one we use in our everyday life. The Roman statue of Juno, illustrating Rancière's regime

\footnotetext{
See: Ibid., p. 22.

See: R. Czekaj, Aesthetics and the Political Turn in Art, “Art Inquiry”, vol. XVII (XXVI), 2015, p. 83-92.
} 
of interpretation, was not created by accident. It is the same statue which was mentioned in one of Frederick Schiller's "Letters on the Aesthetic Education of Man". Here is how Schiller describes it:

The whole form rests and dwells in itself a fully complete creation in itself and as if she were out of space, without advance or resistance; it shows no force contending with force, no opening through which time could break in. ${ }^{9}$

Thus, Schiller's point of view requires that in a piece of art we should perceive space which is not governed by external reality. And that is why Schiller calls art "free appearance". Art is free as it is independent from external reality, it is free appearance because it does not belong there, so in a sense it itself is not real, or belongs to a different reality at the very most. Consequently, in Schiller's opinion, an only adequate reaction of someone looking at a piece of art seen as free appearance is "play drive" when all so far existing coordinates of sense experience are eliminated. We are no longer subject to the distribution of, inter alia, time, place, space, or identity - the categories which enable us to experience reality and which define our existence in the world.

The virtual suspension which according to Schiller's interpretation we experience in the face of art becomes real in Rancière's approach. An artistic act becomes a process of the distribution of the sensible:

I call the distribution of the sensible the system of self-evident facts of sense perception that simultaneously discloses the existence of something in common and the delimitations that define the respective parts and positions within. A distribution of the sensible therefore establishes at one and the same time something common that is shared and exclusive parts. This apportionment of parts and positions is based on a distribution of spaces, times, and forms of activity that determines the very manner in which something in common lends itself to participation and in what way various individuals have a part in this distribution. ${ }^{10}$

Distributing the sensible, art retunes the optics in which the world appears to us and in this sense it alters the parameters of the reality we experience. Each esthetic gesture means drawing new lines between the permitted and the prohibited, between the accepted and the rejected and excluded; each esthetic

9 F. Schiller, "Letter XV", in Letters Upon The Aesthetic Education of Man. http://legacy.fordham.edu/halsall/mod/schiller-education.asp (20.06.2019).

10 J. Rancière, The Politics of Aesthetics. The Distribution of the Sensible, transl. G. Rockhill, Continuum, London 2004, p. 12. 
gesture sets a new boundary between the visible and the invisible in public space. And it is on this classification that Rancière's conception of political nature of art was founded; it does not involve merely adopting a particular position or expressing certain views (as it would happen in the ethical regime). Art is politics through introducing a type of time and space, through the way in which it divides the time and populates the space.

Rancière's concept of the political nature of art and the esthetic regime which determines the concept constitute a really popular tool for interpreting and describing artistic phenomena, especially those socially engaged. The proposed instruments are not always appropriate for the purpose in an obvious sense and they can be misleading.

Let me use an example - in 2014 Łukasz Surowiec and Alicja Rogalska launched a project called Purchase of tears (Skup tez) in Lublin. It was launched in 1 May Street famous for numerous pawnshops where actually anything could be pledged or purchased, there they set up a small shop in which tears were bought. Special laboratory glassware was provided to collect the material on site. To those interested even onions were made available in case of problems with shedding tears. The volumes of the material were meticulously measured and cash was paid for given quantities of tears. The shop was literally besieged by volunteers. The price of $3 \mathrm{ml}$ of tears was 100 zlotys. The authors of the project stated that the place was not randomly selected. Unemployment rate in this area considerably exceeds the Lublin average and most of the commercial space is occupied by the aforementioned pawnshops. The inhabitants of the street were offered a possibility to sell their worries - crying them out at a defined rate.

Can we call the project an artistic political action, in the sense in which Rancière writes about political nature of art? We should remember that the esthetic interpretation regime which determines visibility of art as politics is described according to Schiller's approach in which art is perceived as "free appearance", i.e. a space which cannot be "invaded by the world". However, the action of Surowiec and Rogalska had a radically different direction: it was actually an invasion of particular reality. The way in which I told the story of Purchase of tears places it rather in the ethical regime. There is some kind of ethos present in the project - the ethos of involvement. We become involved whenever we see a necessity of taking action. Also the esthetic regime is involved here as the action taught us a certain lesson. The reality of 1 May Street contradicted the artists' knowledge of what reality should be like.

Purchase of tears can also be perceived from the angle of regime of representation. Then we will be less interested in what exactly the performance involved and what the authors' intentions were as it is possible to bring the visual aspect of the project to the fore. Tears were shed in front of mirrors 
behind which cameras recording all the activities were mounted. The images of the participants resorting to all possible means to make themselves cry, their efforts to fill the vials with the liquid flowing from the corners of their eyes proved to be a really excellent video recording; the authors used the documentation of the project skillfully transforming it into a gallery exhibit. ${ }^{11}$

This does not mean that Purchase of tears cannot be placed in the esthetic regime of interpretation. Rogalska and Surowiec introduced new distribution of coordinates of sense experience. The existing parametres became suspended, as earlier the necessity of pledging one's belongings in a pawnshop was merely a form of economic violence. The violence was not eliminated, as it was played in a new symbolic arrangement, it was no longer the fate of individuals - it became the experience of the community. In this meaning an esthetic gesture became a political gesture.

The three interpretation regimes could be treated as equal and equivalent conditions of visibility and recognizability of art as such. Rancière's texts, however, show that he does not treat them as equivalent. The esthetic and the representation regime are subject to specific rules. Ethos is always confident and knows what should be done, what should be taught, what ideas art should convey and what kind of content is undesirable. On the other hand, the esthetic regime is restricted/limited by the reality of the world which it depicts. Even nonrepresentational art is always bound with a circle of rules which it sets according to its particular formal principles.

Nevertheless, the ethical regime seems to be free and open. Actually, it also establishes its own rules, yet they do not constitute limitation for art. The sphere of sensual experience is shaped according to these principles and the routine everyday practices appear in a different light. In Rancière's approach art is free yet it is not appearance as it actually draws lines, not on canvas but in the space of the visible, it does not shape sculptures but the space of common life.

Evidently, the conception of interpretation regimes is actually constructed from the contemporary point of view on art, taking into consideration what so far has happened in this field. Thus, Rancière did not avoid the trap into which all historical attempts to draw the boundaries of art had fallen. The reason is that we cannot exclude the occurrence of artistic phenomena which will not belong to any of the present regimes and new different regimes will have to be proposed. And once again, theory will have to keep pace with practice.

11 Andit is in this form Purchase of tears by Rogalska and Surowiec can be seen in galleries. 


\section{BIBLIOGRAPHY:}

Dziamski Grzegorz (1996) Postmodernizm wobec kryzysu estetyki wspótczesnej, Poznań: Wydawnictwo Naukowe UAM.

Schiller Friedrich (1983) Letters Upon The Aesthetic Education of Man, transl. E. M. Wilkinson and L. A. Willoughby [1967], Oxford: Clarendon Press.

Rancière Jacques (2009) Aesthetics and its Discontents, transl. S. Corcoran, Oxford: Polity Press.

Rancière Jacques (2004) The Politics of Aesthetics. The Distribution of the Sensible, transl. G. Rockhill, London: Continuum.

\section{PORZAZDKI INTERPRETACYJNE SZTUKI (streszczenie)}

W tekście hasłowo przywołuję problem demarkacji sztuki i XX wieczne próby jej definiowania podejmowane na gruncie filozofii analitycznej. Przyjmuję interpretację, że są one wyrazem rozpoznania zasadniczej niemożliwości wskazania jakichkolwiek własności, którymi w sposób konieczny lub wystarczający powinien charakteryzować się przedmiot o statusie dzieła sztuki. Stąd zaczęto więc pytać nie o to, czym jest dzieło sztuki, ale o kontekst w jakim sztuka się konstytuuje. Jedną propozycji jest koncepcja Jaquesa Rancière’a mówiąca o różnych “porządkach interpretacyjnych sztuki”. W najbardziej ogólny sposób można ją sprowadzić do twierdzenia, że to jakie przedmioty będą rozpoznawalne jako dzieła sztuki jest kwestią dominującego dyskursu. To on decyduje o tym, które działania będą postrzegane jako praktyka artystyczna, a produkty tych działań jako dzieła sztuki. W prezentowanym tekście omówię rozpoznane przez Rancière’a porządki interpretacyjne i podejmę próbę skonfrontowania ich z dzisiejszą praktyką artystyczną.

Słowa kluczowe: porządki interpretacyjne sztuki, Jacques Rancière, Fryderyk Schiller, Skup tez

Rafał Czekaj - PhD, since September 2011 assistant professor (adiunkt) at Maria Curie-Skłodowska University (UMCS) in Lublin, Department of Esthetics, Faculty of Philosophy and Sociology. Author of the book: Krytyczna teoria sztuki Theodora W. Adorna (2013). Areas of research: philosophical aesthetics and social contexts of art. 